\section{To: (Receiving Organization) DISTRIBUTION}

5. Proj./Prog./Dept./Div.: 101-SY HYDROGEN MITIGATION

8. Originator Remarks:

THIS DOCUMENT IS BEING TRANSMITTED FOR APPROVAL AND RELEASE

3. From: (originating organization)
MITIGATION EQUIPMENT

\section{Cog. Engr.:}

G.F. VARGO, JR.

3. From: (Originating Organization)

.

(1)

AND

\section{Receiver Remarks:}

4. Related EDT NO.:

$$
N / A
$$

7. Purchase Order No.:

$$
N / A
$$

9. Equip./Component No.:

$$
N / A
$$

10. System/Bldg./Facility:

TANK 241-SY-101

12. Major Assm. Dwg. No.:

$$
N / A
$$

13. Permit/Permit Application No.: $N / A$

14. Required Response Date: 2/15/1995

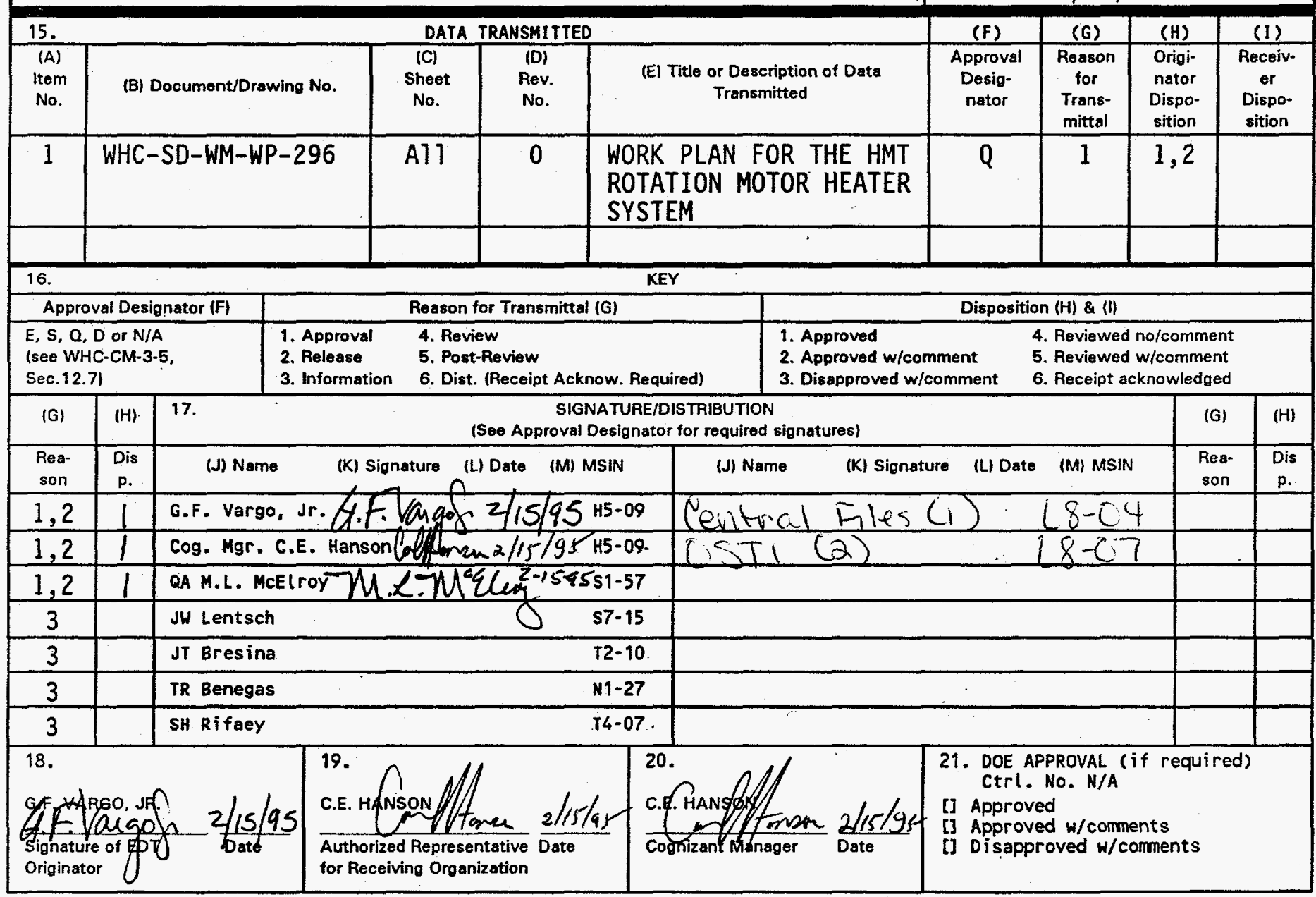




\section{DISCLAIMER}

Portions of this document may be illegible in electronic image products. Images are produced from the best available original document. 


\section{RELEASE AUTHORIZATION}

Document

Number:
WHC-SD-WM-WP-296, Rev. 0

Work Plan for the Hydrogen Mitigation Test (HMT)

Rotation Motor Heater System
Document

Title:

February 16, 1995

This document was reviewed following the
procedures described in WHC-CM-3-4 and is: APPROVED FOR PUBLIC RELEASE

\section{WHC Information Release Administration Specialist:}

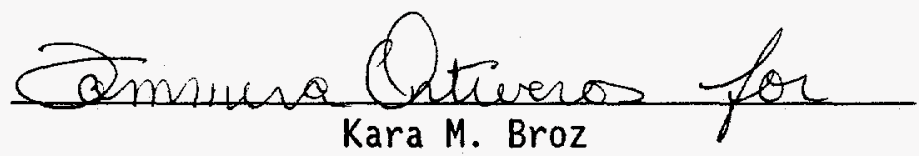

February 16, 1995

TRADEMARK DISCLAIMER. Reference herein to any specific commercial product, process, or service by trade name, trademark, manufacturer, or otherwise, does not necessarily constitute or imply its endorsement, recomendation, or favoring by the United States Government or any agency thereof or its contractors or subcontractors.

This report has been reproduced from the best available copy. Available in paper copy and microfiche. Printed in the United States of America. Available to the U.S. Department of Energy and its contractors from:

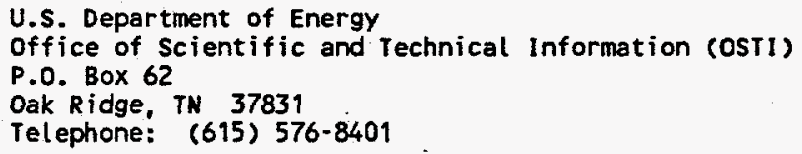

Available to the public from:

U.S. Department of Commerce

National Technical Information Service (NTIS)

5285 Port Royal Road

Springfield, VA 22161

Telephone: (703) 487-4650 
2. Title

WORK PLAN FOR THE HYDROGEN MITIGATION TEST (HMT) ROTATION MOTOR HEATER SYSTEM

5. Key Words

Work plan, HMT, Rotation Motor Heater System

3. Number

WHC-SD-WM-WP-296

6. Author

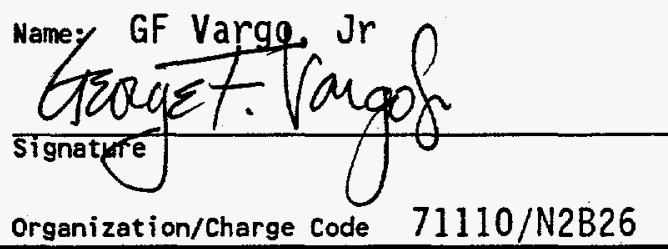

7. Abstract

Workplan to design, fabricate, and install a heater system and cover hood for the HMT rotation motor and gearbox.

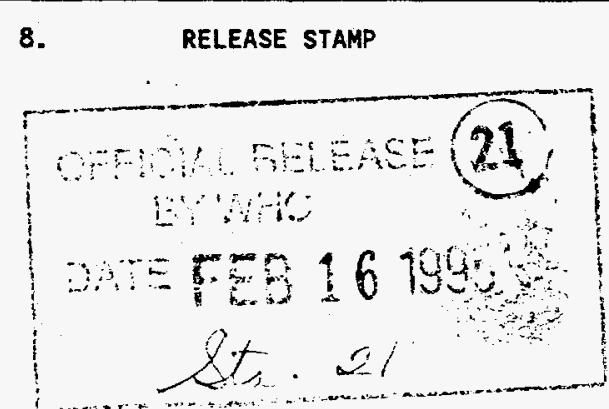


WHC-SD-WM-WP-296

Rev 0

\title{
WORK PLAN FOR THE HYDROGEN MITIGATION TEST (HMT) ROTATION MOTOR HEATER SYSTEM
}

\author{
DISCLAIMER
}

This report was prepared as an account of work sponsored by an agency of the United States Government. Neither the United States Government nor any agency thereof, nor any of their employees, makes any warranty, express or implied, or assumes any legal liability or responsibility for the accuracy, completeness, or usefulness of any information, apparatus, product, or process disclosed, or represents that its use would not infringe privately owned rights. Reference herein to any specific commercial product, process, or service by trade name, trademark, manufacturer, or otherwise does not necessarily constitute or imply its endorsement, recommendation, or favoring by the United States Government or any agency thereof. The views and opinions of authors expressed herein do not necessarily state or reflect those of the United States Government or any agency thereof.

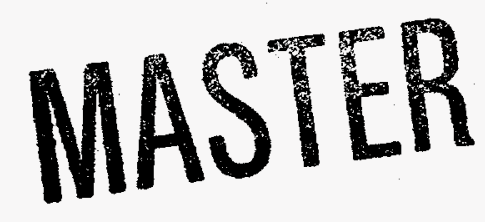

\section{WESTINGHOUSE HANFORD COMPANY FEBRUARY 1995}

DISTRIEUTIOAOTIS DOCUMENT IS UNLIMITED

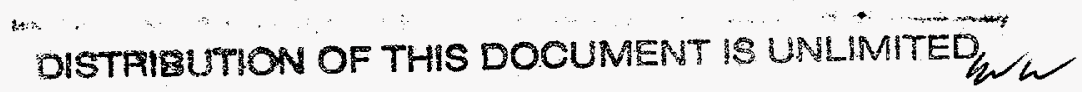


WHC-SD-WM-WP-296

Rev 0

TABLE OF CONTENTS

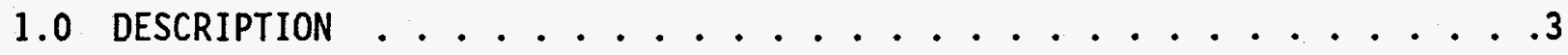

2.0 RESTRICTIONS AND/OR SPECIAL CONDITIONS . . . . . . . . . . . 3

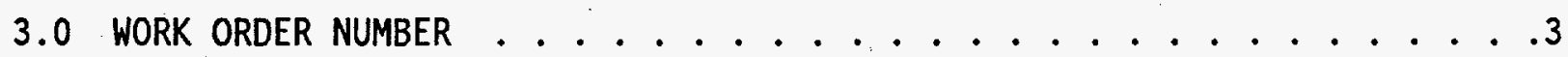

4.0 INSPECTION CRITERIA . . . . . . . . . . . . . . . . . . . 3

5.0 MATERIAL REQUIREMENTS . . . . . . . . . . . . . . . . . 4

6.0 SPECIAL TESTING REQUIREMENTS . . . . . . . . . . . . . . . 4

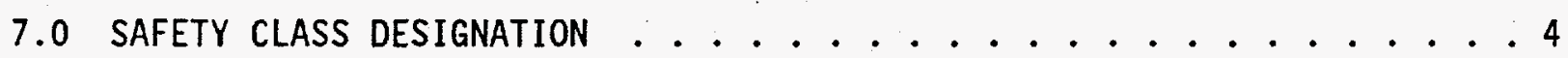

8.0 APPROVAL DESIGNATOR . . . . . . . . . . . . . . . . . . . 4

9.0 SHIPPING AND HANDLING INSTRUCTIONS ................... . 4 10.0 DELIVERY DATE . . . . . . . . . . . . . . . . . . 4 APPENDIX . . . . . . . . . . . . . . . . . . . 5 
WHC-SD-WH-WP-296

Rev 0

ACRONYMS AND ABBREVIATIONS

DACS Data Acquisition and Control System

HP Horsepower

Volts Alternating Current

VSD

Variable Speed Drive

Page 2 
WHC-SD-WM-WP-296

Rev 0

WORK PLAN FOR THE HYDROGEN MITIGATION TEST (HMT)

ROTATION MOTOR HEATER SYSTEM

\subsection{DESCRIPTION}

This document is the work $\mathrm{plan}$ to design, fabricate, and install a heater system and cover hood for the Hydrogen Mitigation Test (HMT) rotation motor and gearbox. This hardware will be fabricated under Development Control, with facility use potentia7, as defined in WHC-CM-6-1, Standard Engineering Practices, EP-2,4. The rotation motor assembly, during cold weather conditions, has experienced freezing causing the motor not to operate. The motor type is a $440 \mathrm{vac}$, I HP squirrel cage induction motor, totally enclosed, and mounted vertically. It is driven by a 5 HP VSD controlled from the DACS. The software program controlling the motor applies a minimum torque to the motor. Therefore, if any resistance from ice or frost is encountered the motor will not turn.

A strip heater system shall be designed to keep the gearbox assembly above 50 degrees $F$. Additionally, a light gauge sheet metal hood shall be designed to cover the motor and gear box assembly from the weather. The heater system shall be mounted to the gearbox and controlled via a thermostatically cycled power supply on a maintained circuit. It shall have a thermocouple to supply the feedback signal to the self-contained controller. The system shall be self-contained and require low maintenance. The design shall allow for manual starting of the system. Furthermore, loss of power or over temperature shall open the electrical power and cause a manual re-start of the system. The control box shall be locally mounted and be environmentally protected. Furthermore, the functionality of the system shall feature a POWER ON, STOP, HEATER POWER-ON, and HEATERS-ON switches and lights located on the front cover.

\subsection{RESTRICTIONS AND/OR SPECIAL CONDITIONS}

None.

\subsection{WORK ORDER NUMBER}

This hardware is being fabricated under Internal Work Order E40536 to Fabrication Services, Organization Number 52100. The Charge Code N2B41 is issued by Mitigation Equipment, Organization \#71110. 
WHC-SD-WH-WP-296

ReV 0

\subsection{INSPECTION CRITERIA}

No special inspections are required. However, the normal fabrication inspection will be performed by the shop foreman.

\subsection{MATERIAL REQUIREMENTS}

A11 material shall be supplied by Mitigation Equipment except for those materials noted on the drawings. These drawings shall be submitted to Fabrication Services with the materials when the job is submitted for fabrication. Reference APPENDIX for a list of the drawings.

\subsection{SPECIAL TESTING REQUIREMENTS}

Basic electrical tests shall be performed by the fabricator. Additionally, a functional test shall be performed under the direction of the cognizant engineer.

\subsection{SAFETY CLASS DESIGNATION}

46.

The safety class designation is a 4 (four) in accordance with WHC-CM-4-

\subsection{APPROVAL DESIGNATOR}

The approval designator is $Q$ in accordance with WHC-CM-3-5, Section 12.7 .

\subsection{SHIPPING AND HANDLING. INSTRUCTIONS}

No special shipping and handling instructions are required. Upon completion of the work the shipping details will be specified by the cognizant engineer.

\section{DELIVERY DATE}

All fabrication and testing shall be completed by March 23, 1995. 


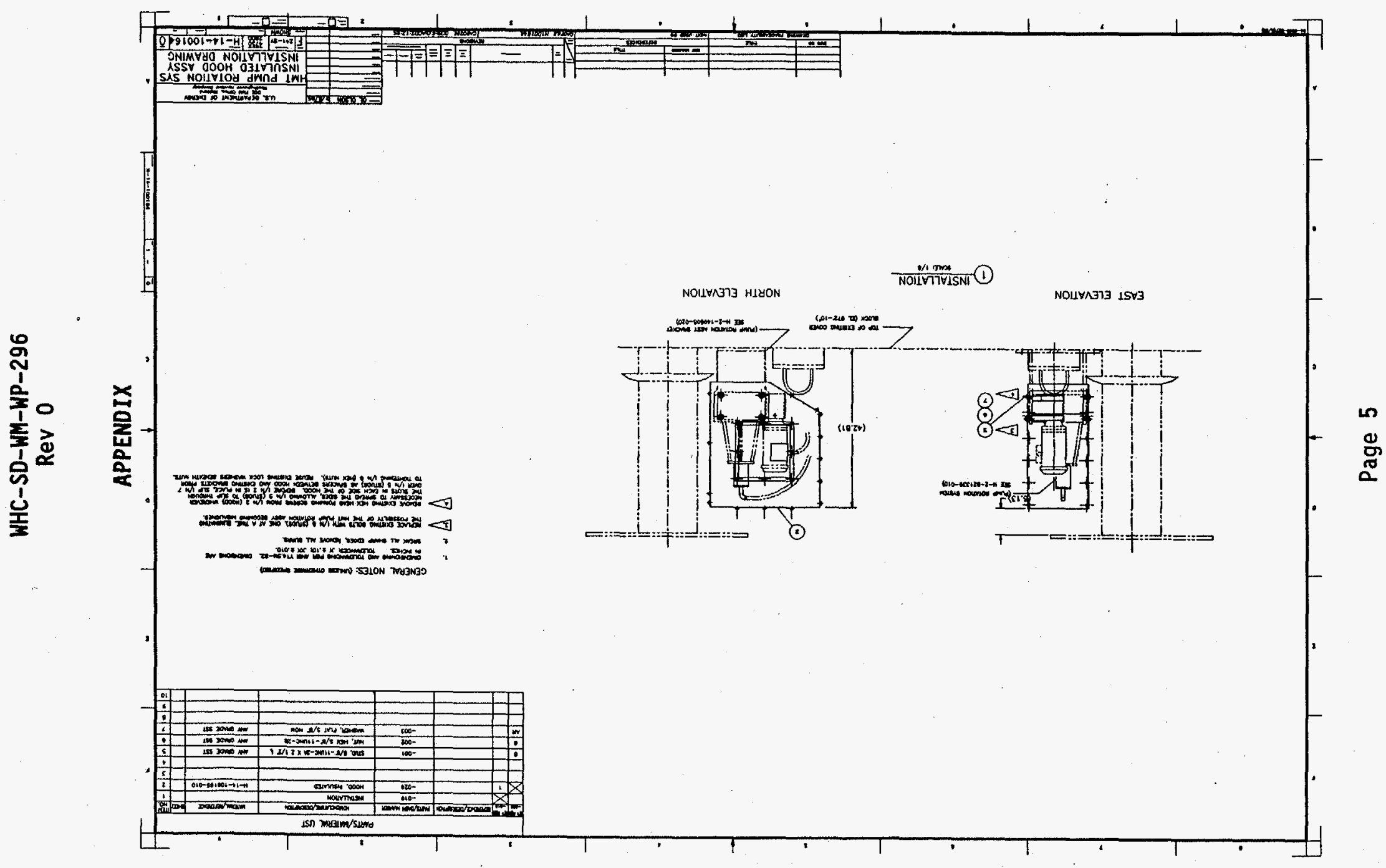


WHC-SD-WH-WP-296

Rev 0

APPENDIX

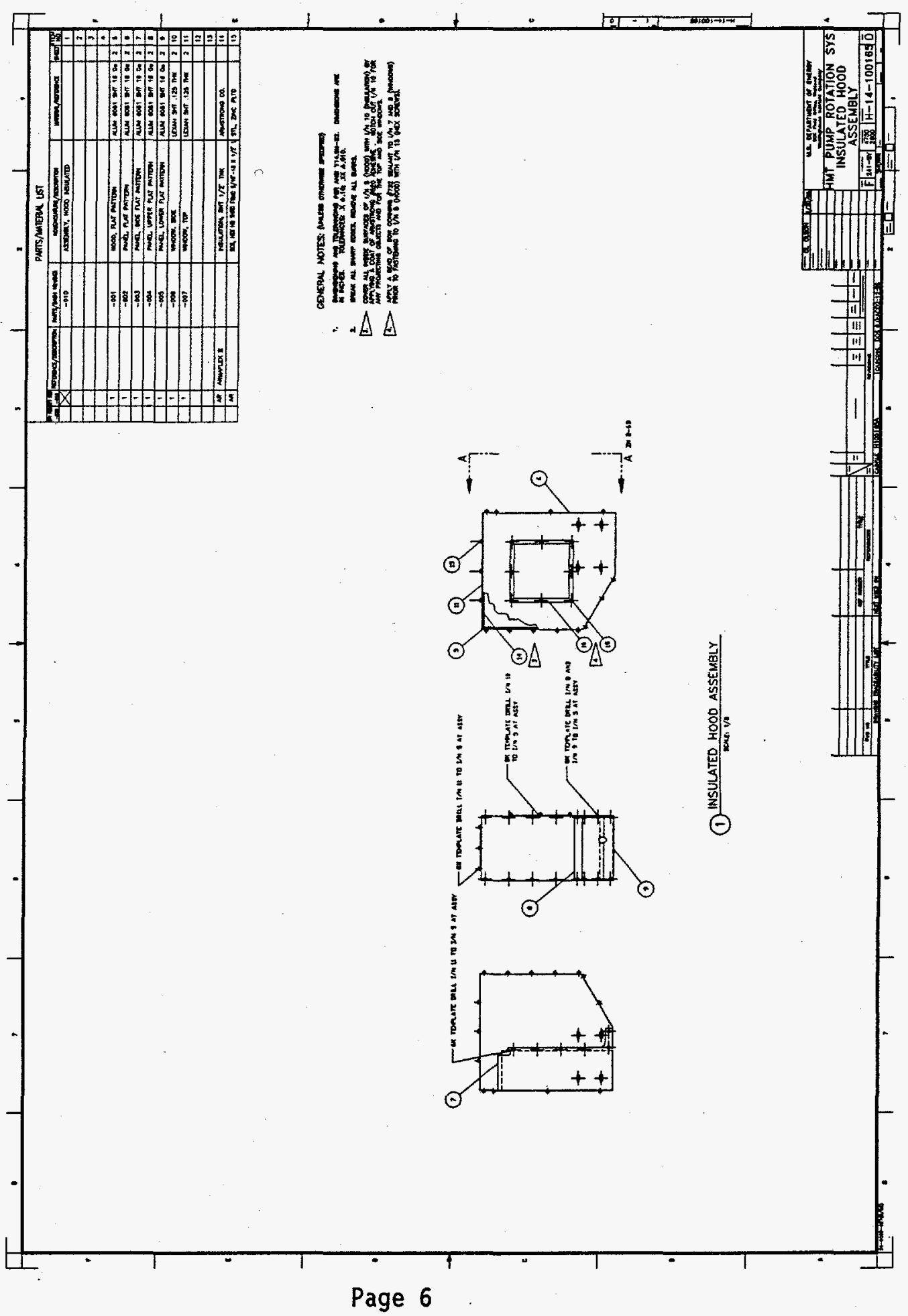


WHC-SD-WH-WP-296

Rev 0

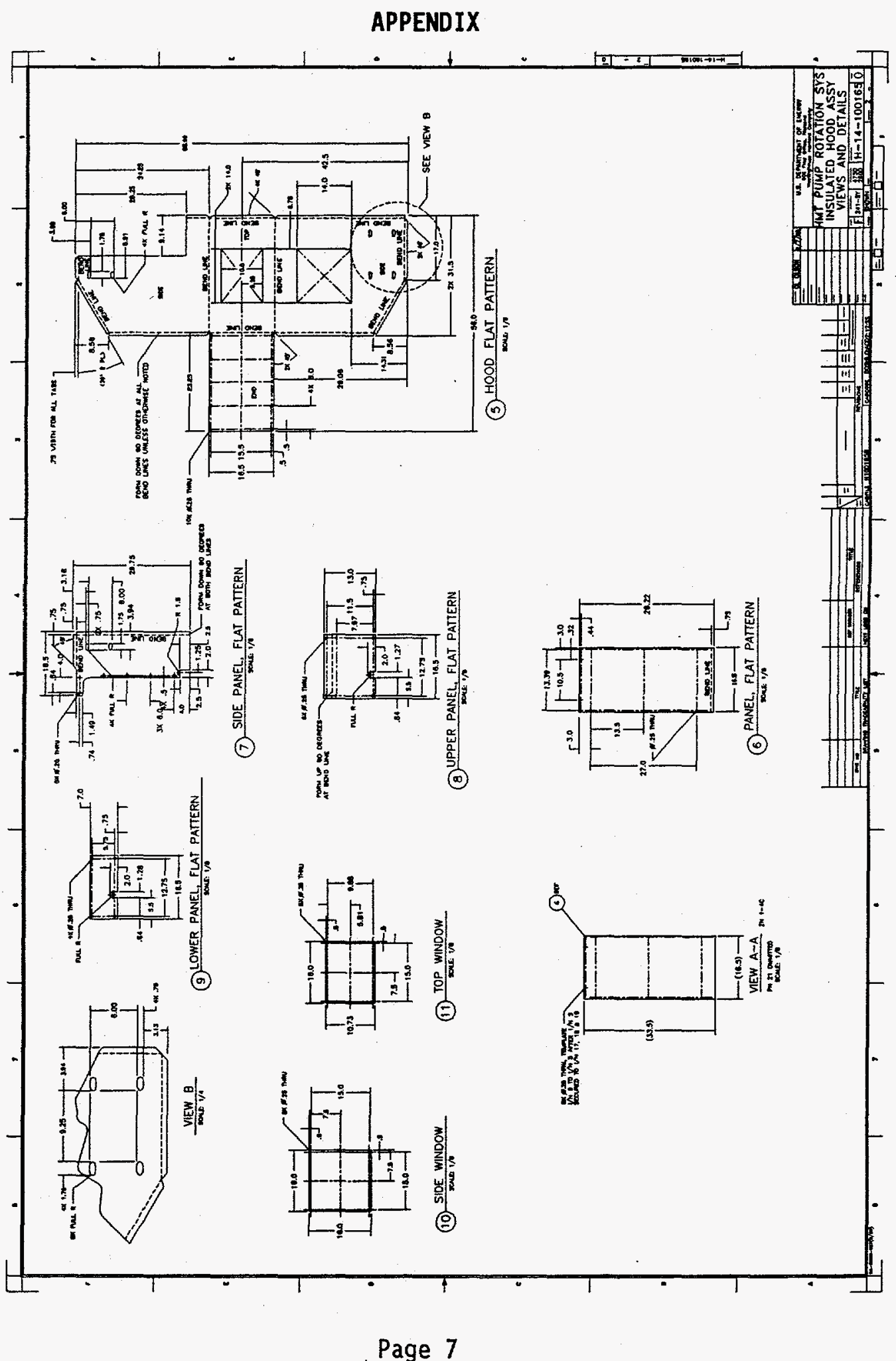




\section{WHC-SD-WH-WP-296 \\ Rev 0}

\section{APPENDIX}

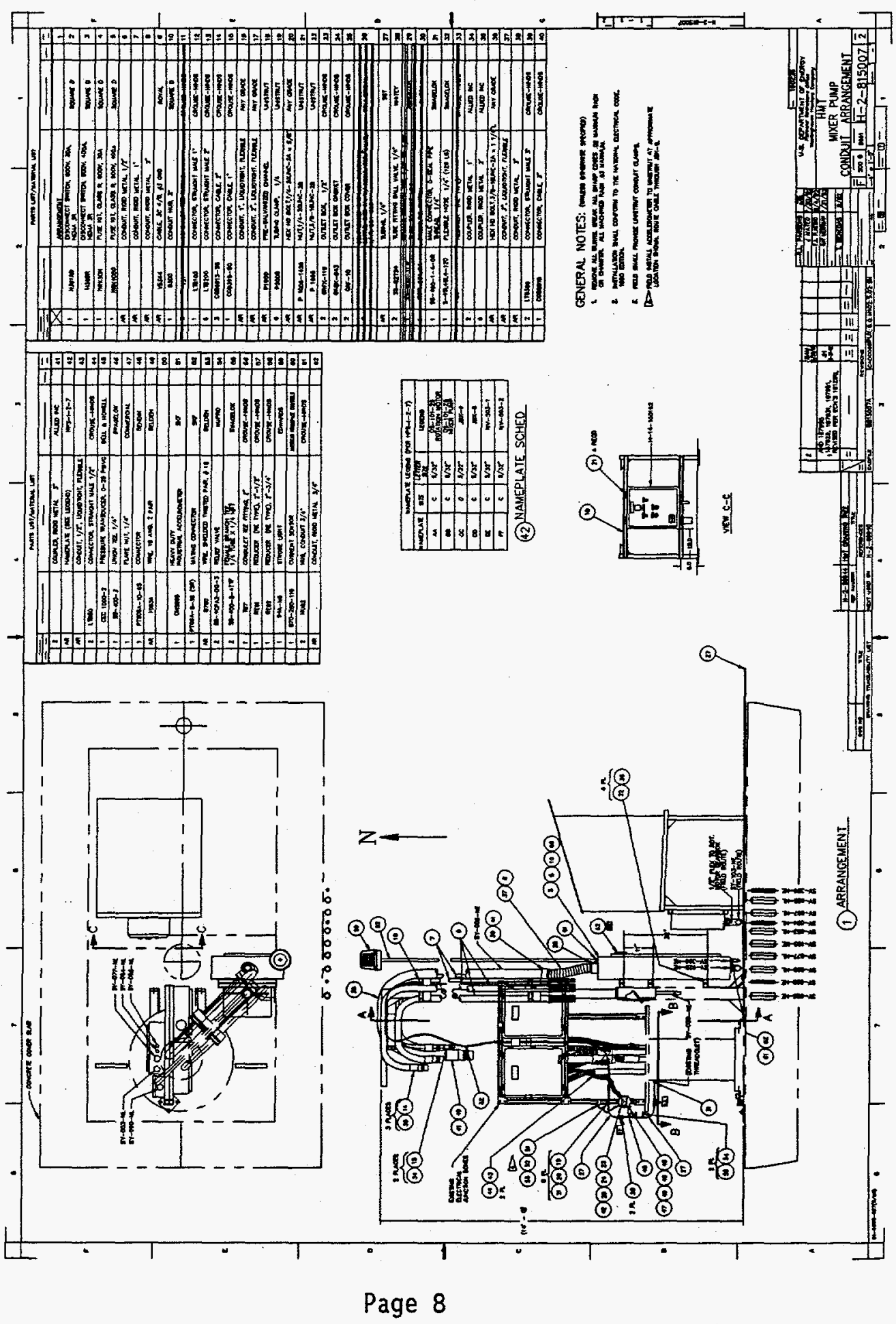


WHC-SD-WM-WP-296

ReV 0

APPENDIX

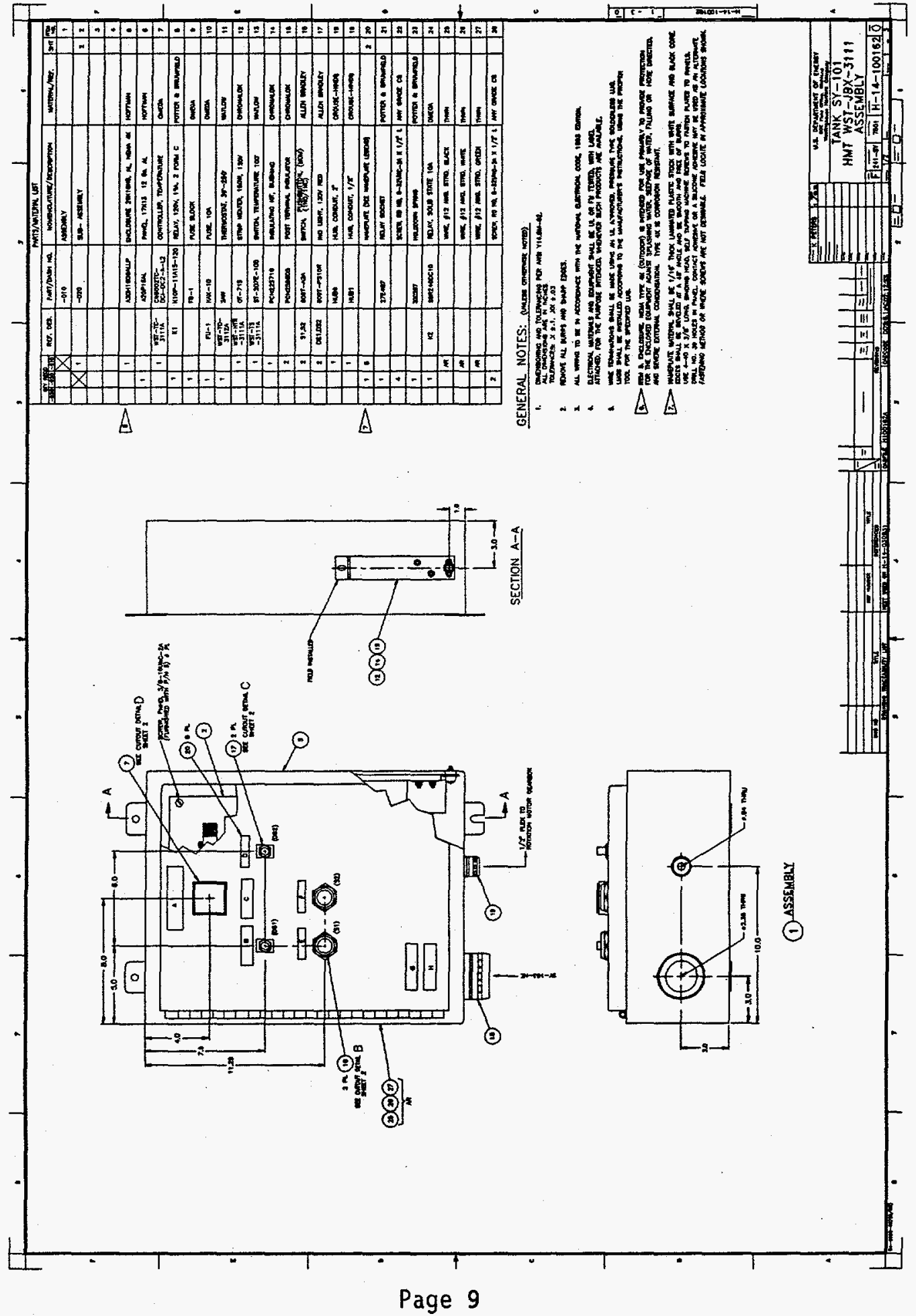




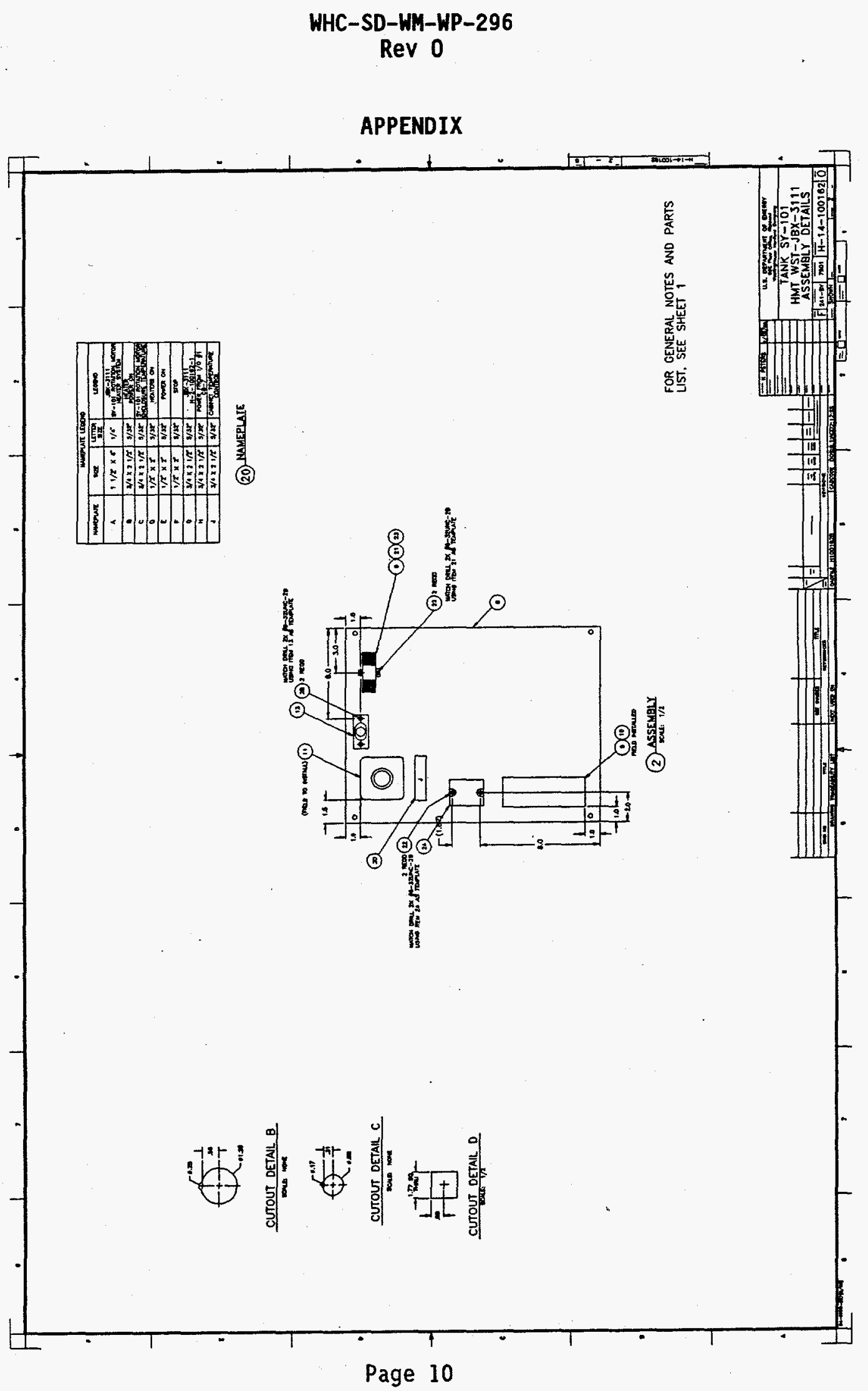




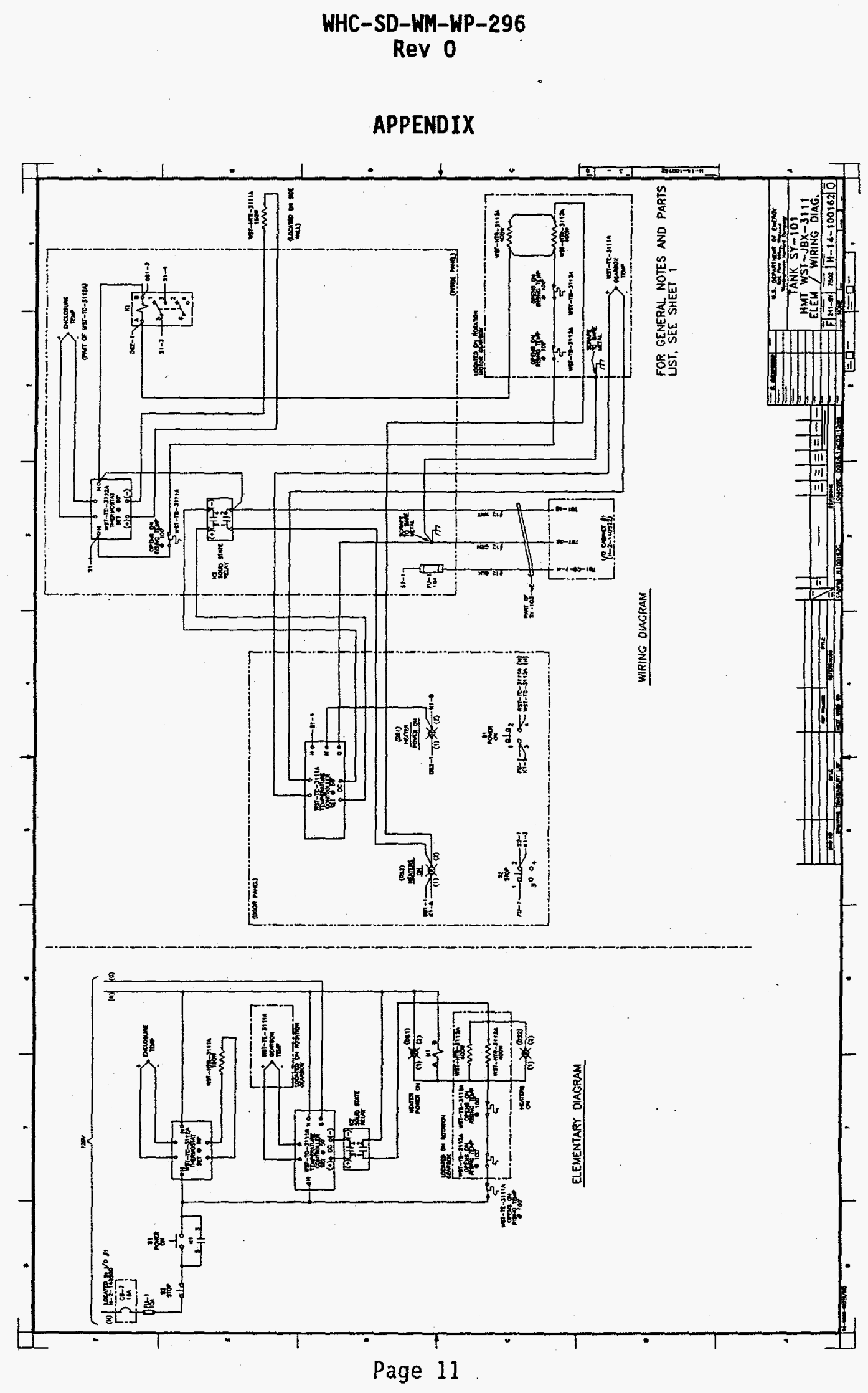

